\title{
RIGHT AND WRONG FROM THE PERSPECTIVE OF 8- AND 12-YEAR-OLD CHILDREN: AN EXPLORATORY ANALYSIS
}

\section{Kira Ammann}

\begin{abstract}
Understanding rights not only means knowing what is permitted by law and what is not, but also being aware of and knowing one's own rights as a human being. This analysis explores how children understand right and wrong, how they gain moral orientations and a sense of justice, and whether they are aware of human rights and children's rights, and if so to what extent. Twelve children aged either 8 or 12 participated in an interview on a dilemma story, as pioneered by Kohlberg, and were also asked about children's rights and human rights. Qualitative content analysis showed that the majority used moral judgements based on fairness and justice, taking the view that behaviour that is wrong should be duly punished. Eight children were able to make substantive statements on human rights; of the eight, three also had some knowledge of children's rights. There were differences between the types of arguments used by the two age groups. There were also some differences between boys and girls, but they were negligible. In German-speaking countries there is little empirical research on children's rights. Few studies have focused on the topic of human rights from the perspective of educational science, and there is also little research on moral concepts and children's rights. What follows is therefore a first attempt to link two neglected research topics.
\end{abstract}

Keywords: justice and injustice, children's and human rights, interviews with children, child perspective, dilemmas, Lawrence Kohlberg

Kira Ammann is a research assistant and $\mathrm{PhD}$ candidate in the Department of General and Historical Educational Science at the University of Bern, Institute of Educational Science, Department of General and Historical Educational Science, Fabrikstrasse 8, 3012 Bern, Switzerland. Email: kira.ammann@edu.unibe.ch 
International Journal of Child, Youth and Family Studies (2018) 9(2): 109-124

Moral decisions and judgements not only express opinions about values and attitudes, but also prioritize some social values over others. Children can only answer moral questions if they have moral orientations that enable them to make decisions about behaviour in concrete situations. Depending on the situational context, these orientations are usually general and can be expressed as abstract behavioural maxims and rules, such as "share fairly" or "be helpful". In concrete everyday situations, children have to decide which moral rules are of importance while taking into account situational conditions and morally significant assessments. How they will actually behave, however, is unpredictable. For this reason, this study combines cognitive and behavioural aspects and defines morality as "judging and acting both autonomously and responsibly in social conflicts" (Steffek, 1999, p. 1). ${ }^{1}$

According to Nunner-Winkler (2003), moral development is best understood as a two-stage process. Children already have an appropriate knowledge of morals at an early stage. They know simple rules and understand that these rules are universally valid, regardless of authority and sanctions. They derive their first moral knowledge from everyday practices and experiences (NunnerWinkler, 2003). Moral motivation then builds up in a second, differential learning process, which strongly depends on the child's family context (Nunner-Winkler, 2007b, 2008b). In order to be able to apply moral norms to everyday situations, however, children must develop a complex knowledge system and the necessary cognitive structures (Nunner-Winkler, 2007b). Children do not simply adopt adult moral rules, but translate them in a nuanced manner to their everyday worlds and are thus able to act and behave morally (Neuhäuser \& Rülcker, 1991).

Research on moral judgements usually focuses on investigations into normative thinking; to date there has been little work on the development of a sense of justice in children (Weyers, 2012). However, understanding legal structures from the perspective of children and adolescents is not only of theoretical interest but also of practical importance. Children's and adolescents' understanding of laws and norms plays an important role in their understanding of rules of conflict, norm violations, criminal justice, the binding nature of agreements and promises, and democracy (Weyers, Sujbert, \& Eckensberger, 2007). Legal awareness refers to a condition "in which a human being sees him-/herself as part of and contributing to a culture which recognizes the individual as an autonomous legal entity, while the social whole qua legal system provides the principal orientation for social action" (Lampe, 1997, p. 11). Studies show that while children up to the age of 9 or 10 do not distinguish between law and morality (Weyers, 2014), early forms of legal awareness are already recognizable from the second year of life (Weyers et al., 2007).

In the past two decades, no one has had a greater influence on both the theory of moral education and the practical pedagogical efforts to promote young people's ethical behaviour than

\footnotetext{
${ }^{1}$ Unless otherwise noted, all translations are the author's.
} 
the psychologist and educationist Lawrence Kohlberg (1927-1987). ${ }^{2}$ Focusing especially on adolescents and adults, his main assumption is "that the development of moral thought follows a universal sequence of distinct stages" (Tapp \& Kohlberg, 1971, p. 67). For Kohlberg, moral judgements are normative, prescriptive ideas about the social world and one's own actions, linked to convictions on how to act (Eckensberger \& Breit, 1997). However, moral judgements are not virtues but constructions that are actively formed by the subject through concrete actions and related discussions (Eckensberger \& Breit, 1997). According to Kohlberg (1981, p. 39), "there is only one principled basis for resolving claims: justice or equality". In his theory, justice is the central principle for resolving situations in which there are unresolved conflicting claims: "A resolution of the situation is one in which each is 'given his due' according to some principle of justice that can be recognized as fair by all the conflicting parties involved" (Kohlberg, 1973, p. 633).

\section{Legal Awareness and Children's Rights}

To learn how children come to understand right and wrong, it is particularly important, from the point of view of developmental psychology, to look at their cognitive and moral development. This is why the present study takes as its starting point Kohlberg's (1981) discussion of the theory of moral development. This investigation works from the assumptions that there is such a thing as moral development and that it is important for the development of legal awareness.

As a moral entity, a human being relates not only to himself or herself, but also to the welfare of human society. Moral questions, therefore, concern one's own behaviour in relation to other people (Herzog, 1991). Moral issues are public issues that affect social relations. Recognizing human dignity is not only a cognitive act, but a moral feeling: moral because it provides criteria to judge one's actions, or failure to act; and a feeling because these criteria are not calculated, but represent an all-embracing, seemingly spontaneous attitude that opens up the world (Brumlik, 2004). It is, therefore, necessary to develop moral judgement and moral feeling (König \& Seichter, 2014). From the perspective of educational science, the question arises as to how it might be possible to collectively strengthen both the idea of children's and human rights and the will to realize them in pedagogical activities and situations (König \& Seichter, 2014).

Children are legal persons in a particular way. In their early years, it is their parents, their legal guardians, or the state who execute their rights. While growing up, as children gradually gain more life competences, they need special protection and support as well as child-friendly forms of participation that are appropriate to their stage of development. Children "are not 'less' than adults (less cunning, less experienced, less informed and less competent) - children are primarily different" (Oser \& Althof 1992, p. 39). While they share with adults basic needs such as food, education, love, and care, their other interests may differ significantly, depending on their circumstances or living conditions. For this reason, the Convention on the Rights of the Child (CRC)

2 In recent years, numerous publications have explored the topic of moral development. In addition to Kohlberg the works of Nunner-Winkler (2003, 2007a, 2007b, 2008a) and Weyers $(2004,2005,2012,2014)$ on moral development have been particularly important for my investigations. 
International Journal of Child, Youth and Family Studies (2018) 9(2): 109-124

summarizes the universal needs of all children and stipulates that these needs must be met (Rossa, 2014). The principles set out in the CRC codify respect for the basic human values and dignity of children (Maywald, 2008). The Convention advocates a holistic approach that strengthens children's rights to protection, support, and participation in those areas of life that are important to them. In this way, human rights always have an emancipatory, empowering potential (Mader, 2007).

The question of why children need special rights is, therefore, not answered only by their greater need for protection, but also by their otherness. Children create their own physical and social worlds and try to understand what they experience and perceive. They observe things and develop their own theories about them, and about their causes and contexts. The same applies to interpersonal and social relations and their rules (Oser \& Althof, 1992). It would therefore be desirable for everyone to understand children's rights in such a way that children and youth can make use of their rights whenever they need them — with the help of adults, if necessary.

\section{Research Questions}

The aim of the interviews was to grasp the argumentation and estimation of children based on a moral dilemma and to find out how much they know about human and children's rights. Few studies have focused on the topic of human rights from the perspective of educational science (Andresen \& Diehm, 2006; Lenhart, 2006; Lohrenscheit, 2004; Stellmacher, Sommer, \& Imbeck, 2003), and there is also little research on moral concepts and children's rights. The research was carried out from April to December 2014 as part of my master's thesis (Ammann, 2014). The research questions were: How do 8- and 12-year-old children understand right and wrong? Are they aware of human and children's rights and, if so, to what extent?

\section{Method}

\section{Participants}

The methodological process consisted of numerous decisions and corresponding clarifications for the interview as well as ethical reflections like questions of consent and choice, power dynamics, and protection from harm in the interview setting (Nixon, 2013), which had to be made in advance. In order to establish contact with possible participants, a fact sheet including information about the study's topic, methodology, contact details, procedure, and data protection was sent to a total of 48 gatekeepers (Helfferich, 2005). They were requested to forward the information to other parents with children fulfilling the participation criteria. Access to the 8-year-old and 12year-old children was thus established by the snowball system (Helfferich, 2005).

The final sample was composed of a total of 12 children aged either 8 or 12 . The average age of the 8 -year-olds was 8 years and 6 months (the youngest was 8 years and 2 months, the oldest 8 years and 10 months) and of the 12-year-olds, 12 years and 8 months (the youngest was 12 years and 2 months, the oldest 12 years and 10 months). All children attended a primary or secondary 
International Journal of Child, Youth and Family Studies (2018) 9(2): 109-124

school in Switzerland. In order to be able to examine gender differences, three girls and three boys in each age group were recruited for the sample. All data, except the age and gender of the interviewed child, were anonymised, and the names of the children were changed.

The selection of these two age groups was based both on Kohlberg's stage theory, according to which these age groups differ in their moral development (Kohlberg, 1968), and on Weber's proposition (2013) that the period between 8 and 12 years is especially suitable for human rights education. As for the socioeconomic composition of the sample, the occupations of the parents were classified using the International Standard Classification of Occupations (ISCO-88). Five children had at least one parent with an academic background; four of these were from the group of 8-year-olds.

All parents consented to their children's participation. The interviewed children, too, were asked to give their oral consent. However, an informed consent in a classical sense cannot be assumed, since it remains an open question when children are old enough to give their consent (Miethe, 2013; Vogl, 2012). In accordance with the Checklist for Research on and with Children from Swissethics (2013), the children were informed orally.

\section{Interviews}

I chose a qualitative approach for the interviews, because it offers direct access to the perspective of the research subject and allows researchers and interviewees to interact in a flexible manner (Heinzel, 2012; Wagner, 2014). Based on Kohlberg's (Colby, Kohlberg, Speicher, Hewer, Candee, Gibbs \& Power, 1987) "Moral Judgement Interview”, I developed semi-structured guidelines for an interview lasting 20 to 30 minutes, a suitable time period if taking into account 8-yearolds' attention and concentration spans (Delfos, 2004). To test its suitability, a pretest interview was conducted with an 8-year-old boy, and analysed with a specialist for forensic and criminal investigations of children. As a further pretest, the interview was repeated in an adapted form with an 11-year-old girl. Previous projects have provided experience in conducting interviews with children.

Qualitative interviews with children are challenging, because their capacity to be actively involved in the research process depends on their intellectual, social, and moral capacities. Taking the children's stage of development into account is essential for adequately implementing the methodology and interpreting their statements and actions (Wagner, 2014). Above all, the children's linguistic ability must be considered. It should be noted, however, that a child does not have the same verbal and pragmatic skills in all situations; rather, these are strongly dependent on context (Vogl, 2012).

The parents and the children had been informed beforehand that the interviews would take place without parents or siblings present. For the interview itself they were asked to leave the room so that the child could react as freely and openly as possible. Parents and children were briefed orally that they could interrupt or cancel the interview at any time. As stated in advance to the 
International Journal of Child, Youth and Family Studies (2018) 9(2): 109-124

parents, the interview recordings were deleted after the analysis to protect the privacy of the participants. After the interviewer had explained the conversation rules, the children were aware that they were the experts and that their opinion was important and interesting. Next, they were told the dilemma story: the story of Mona, a girl, and Till, a boy, two friends on their way home from school. Originally based on Steffek (1999), the story was rewritten in Swiss-German dialect and adapted to correspond with the everyday life experiences of the children in the study. The two friends get harassed by a group of older children from the same school. They take Till's new sneakers and kick Mona in the belly. They threaten to return if Mona and Till tell anyone about the incident. After having been told this story, the children were asked if they had ever heard of such a situation and to discuss possible ways of resolving it (see Ammann, 2014).

If the interviewed child was a girl, the story was adapted so that Till was beaten and Mona had to solve the situation; if the interviewed child was a boy, Mona was beaten and Till had to find a solution. After further questions concerning the story, the second part of the interview was introduced with more general information on human and children's rights. Throughout the interview, an attempt was made to avoid leading or closed yes-no questions. If children knew about children's rights, they were asked in greater detail about what they knew and how they had acquired this knowledge.

To strengthen children's rights worldwide, the United Nations has committed to communicating the principles and provisions of the CRC to children and adults all over the world (Article $42)^{3}$. With reference to this Article, the children were asked at the end of the interview how information on children's rights could be better disseminated; they were also asked to invent a new children's right that they wished would exist.

Similar to the initial phase before the actual interview, a phase after the interview was implemented where the children had the opportunity to bring in their own thoughts and could ask questions. This procedure was intended to ensure that the child was not left with any emotions that could cause negative effects afterwards. The interview situation ended with an appreciation for participating and the handing over of a memory game about human rights as well as a comic about children's rights.

The data evaluation was based on the content analysis recommendations given by Schmidt (2013) for guided interviews and on the computer-based evaluation process according to Kuckartz (2014). Based on the research questions, I developed a system with 9 main categories and 74 subcategories to categorize the relevant facts in the transcribed interviews.

\footnotetext{
${ }^{3}$ See http://www.ohchr.org/en/professionalinterest/pages/crc.aspx
} 
International Journal of Child, Youth and Family Studies (2018) 9(2): 109-124

\section{Results}

First of all, 10 of the 12 children had a good understanding of rules and knew what a rule was. Knowledge of rules was interpreted to mean that the children had moral awareness.

Nine children had heard a story like that of Till and Mona before and were able to elaborate on it when asked. There was no evid0ence to suggest that knowledge of this or a similar situation led to a greater sense of personal concern or a greater willingness to provide more information or more elaborate arguments.

My main finding was that most (10 out of 12) of the interviewed children had a general understanding and knowledge of the situation presented in the story. In both age groups, 5 out of 6 children believed that one should not behave as the older children did in the story. Half of the children assessed the situation with words like "mean", "nasty", or a similar expression. All children but one made at least one moral statement concerning the situation, and one girl explicitly called the situation "extortion". The fact that Mona or Till might feel pain or be injured upon being beaten was not mentioned as an argument for helping the other person.

Almost all children judged the age difference between the attacking group and Mona and Till as unfair and expressed this belief by referring to aspects like age and height (e.g., "The attacking group is older than Mona and Till"), fairness ("It is not fair to behave like this"), and group size ("A majority against only two is unfair"). Ten out of 12 children expressed the view that misconduct should have consequences. Depending on their age, the children proposed different sanctions such as "having to sharpen all one's coloured pencils during the break" (8-year-old) or "cleaning the water closet" (12-year-old).

Further categories were emotions (anxiety, sadness, pain), the kind of helping behaviour (passive vs. active), and friendship issues (friendship plays a role vs. friendship plays no role). Seven children mentioned emotional aspects like sadness and anxiety. Asked what Till should have done to help Mona, or Mona to help Till, the interviewed children differed in their choice of passive or active behaviour, with eight preferring passive behaviour like getting help, running away, or waiting and seeing what would happen. None of the children offered arguments or reasons for helping. Only four mentioned friendship as a reason why Mona should help Till or vice versa. This accords with Smetana, Killen, and Turiel's (1991) finding that, among children, compliance with justice and law are considered more important than friendship issues.

With regards to values and moral norms, I had assumed that the children might argue on the basis of human rights (one has to help to protect human lives), but this was not the case. I suggest that this is due not to a lack of moral development but to a lack of knowledge. If you do not have any knowledge about children's or human rights, you cannot use it as an argument. It is therefore important that children know their rights, so that they can claim them. This underscores the need for comprehensive human rights education in school. 
International Journal of Child, Youth and Family Studies (2018) 9(2): 109-124

Nine children knew what a right was and could name an example ("A right is if you are allowed to do something"). Eight children had a fair knowledge of human rights and mentioned aspects such as war, torture, slavery, money, skin colour, gender equality, and so on. Overall, the children presented two perspectives: rights for all on a general, abstract level ("All humans are allowed to do the same"; "Everyone has the same rights"); and concrete examples from the media as well as from the children's own experiences ("I know that prisoners of war need to be treated properly and fairly; otherwise, you are not allowed to keep them in jail"; "A friend of our family is a human rights lawyer and sometimes she visits murderers"; "It is not fair that dark-skinned people sometimes are not treated well"). Age differences were not detectable. The children who did not know about human rights were all girls, but given the small sample size, we cannot draw any conclusions from this finding.

Only three children knew about the existence of children's rights and were able to say something substantive about them ("Even so children get beaten worldwide"; "Child slavery still exists"; "Children have the right to go to school, even if they do not have enough money"). Eight of the 12 children had never heard about children's rights; one child had heard only a little.

Eleven children affirmed the need for children's rights. The same number had ideas about how to promote children's rights, possibly influenced by examples and ideas mentioned by the interviewer. All the children came up with ideas for new children's rights, such as Lego bricks for every child, or a loving and caring family for every child.

For some of the younger children, imagining the situation of Mona and Till seemed to be unpleasant; their statements did not focus primarily on the dilemma the story presented but on the fact that the two friends were in trouble. They expressed their discomfort through displacement activities such as fumbling with their clothes or shuffling their feet. This interpretation is consistent with other research suggesting that older children have a better control over nonverbal behaviour than younger (Katz et al., 2012). Nevertheless none of these expressions exceeded a critical point of uneasiness. For subsequent questions about the interview, the parents were asked to contact the interviewer if necessary.

The shortest conversation was 13 minutes and 49 seconds; the longest 24 minutes and 39 seconds. The average interview length was 20 minutes. During the interviews, the 8-year-olds talked much more than the 12-year-olds. Given the small size of the sample, the differences by gender were not considered relevant for the present study, but they might be an interesting aspect for further research. Differences in argumentation - for example, with regard to the type of punishment for the attackers - appeared age-appropriate. In both age groups, the girls were more attentive and less shy, perhaps because the interviewer was also female. 
International Journal of Child, Youth and Family Studies (2018) 9(2): 109-124

\section{Conclusion}

Since there is little literature linking the fields of moral development and children's rights, this analysis necessarily has a tentative and explorative character, and the results should be interpreted with caution. Nor is this study representative, given the small sample of 12 children from a relatively homogeneous socioeconomic background.

However, the specific setting of the guided interview allowed deeper insights into the children's thinking processes and abilities than would have been possible in a more standardized research situation (Vogl, 2012). Since all interviews were conducted by the same person, an interviewer bias can not be excluded. As expected, no child had linguistic difficulties. But the children often answered with "Yes", "No", or "Mhm", and not all were able to substantiate their answers, which somewhat limited the content of the data and led to fewer meaningful statements than expected.

The results indicate that 8- and 12-year-old children have an understanding of right and wrong and that moral judgements are important in their assessments of a particular situation. Regarding the statements about the story of Till and Mona, the most frequently mentioned opinion was that one should not behave like the group in the story; the children's argumentation showed that they associated "right" with fairness and justice. Similarly, from the children's point of view, injustice was unfair and wrong. The majority argued in terms of age and height differences, using expressions like "fair" and "not fair". These answers agree with Kohlberg's assumption that justice is best described as fairness orientation:

The principle central to the development of stages of moral judgment, and hence to proposals for moral education, is that of justice. Justice, the primary regard for the value and equality of all human beings and for reciprocity in human relations, is a basic and universal standard. (Kohlberg \& Hersh, 1977, p. 58)

Accordingly, my findings could be interpreted as demonstrating that indicators of justice like age and height, fairness, and group size are key when it comes to determining children's sense of right and wrong.

Further research is needed. For example, this study could be supplemented by interviews with 10- and 14-year-old children, or young adults. It would also be beneficial to take in further variables like moral feelings and motivations, since emotions such as empathy, shame, and guilt are linked to moral principles and moral behaviour.

With regard to the issue of children's rights, the question remains as to who determines what is good and appropriate for children. Especially in connection with the best interests of the child, this question cannot be answered conclusively or universally and still needs a solution. Previous studies have shown that human rights are evaluated differently under a general rather than a contextually-informed view, which means that human rights must be learned through exemplary 
conflict situations (Weyers \& Köbel, 2010). Discussing and understanding human rights in concrete situations is different than just talking about them in an abstract or theoretical manner.

The purpose of this analysis was to expand our understanding of what children perceive as right and wrong and to find out how much they know about human and children's rights. In sum, it can be stated that children do have an understanding of right and wrong and a partial knowledge of human rights. They have little knowledge of children's rights, however, and it seems necessary to invest more in the communication and teaching of children's rights.

Legal awareness and moral knowledge provide a basis for human and children's rights education. Children and young people who receive such an education can pass on their knowledge as adults and thus actively contribute to a democratic society based on the rule of law. Therefore, linking children's and human rights and moral development may prove to be a fruitful subject for further research. 
International Journal of Child, Youth and Family Studies (2018) 9(2): 109-124

\section{References}

Ammann, K. (2014). Recht und Unrecht aus Kinderperspektive. Eine Analyse zum Verständnis von Recht und Unrecht aus der Perspektive von 8- und 12-jährigen Schulkindern [Right and wrong from a child's perspective. An analysis to understand right and wrong from the perspective of 8 and 12 year old schoolchildren] (Unpublished master's thesis). University of Bern, Bern, Switzerland.

Andresen, S., \& Diehm, I. (Eds.). (2006). Kinder, Kindheiten, Konstruktionen. Erziehungswissenschaftliche Perspektiven und sozialpädagogische Verortungen [Children, childhoods, constructions. Educational perspectives and socio-educational localizations]. Wiesbaden, Germany: VS Verlag für Sozialwissenschaften.

Brumlik, M. (2004). Aus Katastrophen lernen? Grundlagen zeitgeschichtlicher Bildung in menschenrechtlicher Absicht [Learning from disasters? Foundations of contemporary history education in human rights]. Berlin, Germany, and Vienna, Austria: Philo \& Philo Fine Arts GmbH.

Colby, A., Kohlberg, L., Speicher, B., Hewer, A., Candee, D., Gibbs, J., \& Power, C. (1987). The measurement of moral judgment: Volume 2, Standard Issue Scoring Manual. Cambridge: Cambridge University Press.

Delfos, M. F. (2004). «Sag mir mal...». Gesprächsführung mit Kindern (4 bis 12 Jahre) ["Tell me...”. Conversing with children (4 to 12 years)]. Weinheim, Germany, and Basel, Switzerland: Beltz.

Eckensberger, L. H., \& Breit, H. (1997). Recht und Moral im Kontext von Kohlbergs Theorie der Entwicklung moralischer Urteile und ihrer handlungstheoretischen Rekonstruktion [Law and morality in the context of Kohlberg's theory of the development of moral judgments and their action-theoretical reconstruction]. In E.-J. Lampe (Ed.), Zur Entwicklung von Rechtsbewusstsein [The development of legal awareness] (pp. 253-340). Frankfurt, Germany: Suhrkamp.

Heinzel, F. (2012). Qualitative Methoden in der Kindheitsforschung [Qualitative Methods in Childhood Research]. In F. Heinzel (Ed.), Methoden der Kindheitsforschung. Ein Überblick über Forschungszugänge zur kindlichen Perspektive [Methods of childhood research. An overview of research approaches to the child's perspective] (pp. 22-35). Weinheim, Germany, and Basel, Switzerland: Beltz Juventa.

Helfferich, C. (2005). Die Qualität qualitativer Daten. Manual für die Durchführung qualitativer Interviews [The quality of qualitative data. Manual for conducting qualitative interviews]. Wiesbaden, Germany: VS Verlag für Sozialwissenschaften. 
International Journal of Child, Youth and Family Studies (2018) 9(2): 109-124

Herzog, W. (1991). Das moralische Subjekt. Pädagogische Intuition und psychologische Theorie [The moral subject. Pedagogical intuition and psychological theory]. Bern, Switzerland: Verlag Hans Huber.

Katz, C., Hershkowitz, I., Malloy, L. C., Lamb, M. E., Atabaki, A., \& Spindler, S. (2012). Nonverbal behavior of children who disclose or do not disclose child abuse in investigative interviews. Child Abuse and Neglect, 36, 12-20. doi:10.1016/j.chiabu.2011.08.006

Kohlberg, L. (1968). The child as a moral philosopher. Psychology Today, 2(4), 25-30.

Kohlberg, L. (1973). The claim to moral adequacy of a highest stage of moral judgment. The Journal of Philosophy, 70, 630-646. doi:10.2307/2025030

Kohlberg, L. (1981). Essays on moral development: Vol. I. The philosophy of moral development. Moral stages and the idea of justice. New York, NY: Harper \& Row.

Kohlberg, L. (1984). Essays on Moral Development. Volume II: The Psychology of Moral Development. The Nature and Validity of Moral Stages. New York: Harper \& Row.

Kohlberg, L. (1995). Die Psychologie der Moralentwicklung [The psychology of moral development]. Frankfurt: Suhrkamp.

Kohlberg, L., \& Hersh, R. H. (1977). Moral development: A review of the theory. Theory Into Practice, 16, 53-59. doi:10.1080/00405847709542675

König, J., \& Seichter, S. (2014). Menschenrechte und Pädagogik. Ansprüche, Wirklichkeiten, Dilemmata und Notwendigkeiten. Zur Einleitung [Human rights and education. Claims, realities, dilemmas and necessities. To the introduction]. In J. König \& S. Seichter (Eds.), Menschenrechte. Demokratie. Geschichte. Transdisziplinäre Herausforderungen an die Pädagogik [Human rights. Democracy. History. Transdisciplinary challenges to pedagogy] (pp. 9-27). Weinheim, Germany, and Basel, Switzerland: Beltz Juventa.

Kuckartz, U. (2014). Qualitative Inhaltsanalyse. Methoden, Praxis, Computerunterstützung [Qualitative content analysis. Methods, practice, computer support] (2nd ed.). Weinheim, Germany, and Basel, Switzerland: Beltz Juventa.

Lampe, E.-J. (1997). Zur Entwicklung von Rechtsbewusstsein. Einleitung [The development of legal awareness. introduction]. In E.-J. Lampe (Ed.), Zur Entwicklung von Rechtsbewusstsein [About the development of legal awareness] (pp. 7-47). Frankfurt, Germany: Suhrkamp.

Lenhart, V. (2006). Pädagogik der Menschenrechte [Pedagogy of Human Rights]. Wiesbaden, Germany: VS Verlag für Sozialwissenschaften. 
International Journal of Child, Youth and Family Studies (2018) 9(2): 109-124

Lohrenscheit, C. (2004). Das Recht auf Menschenrechtsbildung. Grundlagen und Ansätze einer Pädagogik der Menschenrechte [The right to human rights education. Foundations and approaches of a pedagogy of human rights.]. Frankfurt, Germany: IKO-Verlag für Interkulturelle Kommunikation.

Mader, M. (2007). Warum Kinderrechte? [Why children's rights?] In P. G. Kirchschläger, T. Kirchschläger, A. Belliger, \& D. J. Krieger (Eds.), Menschenrechte und Kinder [Human rights and children]. 4. Internationales Menschenrechtsforum Luzern (IHRF) [Human rights and children. 4th International Human Rights Forum Lucerne (IHRF)] (pp. 65-72). Bern, Switzerland: Stämpfli Verlag AG.

Maywald, J. (2008). Die Umsetzung der Kinderrechte als Leitbild in der Arbeit mit Kindern und Jugendlichen [The implementation of children's rights as a guiding principle in working with children and adolescents]. In Sozialpädagogisches Institut des SOS-Kinderdorf e.V. (Ed.), Kinderschutz, Kinderrechte, Beteiligung [Child protection, children's rights, participation] (pp. 48-73). Retrieved from http://v1.bitv-test.de/dateien/pdf_test/1422/dokumentation_6.pdf

Miethe, I. (2013). Forschungsethik. In B. Friebertshäuser, A. Langer, \& A. Prengel (Eds.), Handbuch Qualitative Forschungsmethoden in der Erziehungswissenschaft [Handbook Qualitative Research Methods in Educational Science] (4th ed., pp. 927-937). Weinheim, Germany, and Basel, Switzerland: Beltz Juventa.

Neuhäuser, H., \& Rülcker, T. (1991). 'Na hör' mal, du kannst nich’ so einfach bestimmen, was ich jetzt mache". Moralvorstellungen und wie die Schule damit umgehen kann ["Listen, you can not just decide what I'm doing right now." Moral ideas and how the school can deal with it]. Grundschulzeitschrift, 50, 6-10.

Nixon, E. (2013). Ethics of oral interviews with children. In C. Russel, L. Hogan, \& M. JunkerKenny (Eds.), Ethics for graduate researchers (pp. 183-199). Oxford, England: Elsevier. doi:10.1016/B978-0-12-416049-1.00012-X

Nunner-Winkler, G. (2003). Moralentwicklung im Verlauf des Lebens [Moral development in the course of life]. In W. Schneider \& M. Knopf (Eds.), Entwicklung, Lehren und Lernen [Development, teaching and learning] (pp. 125-145). Göttingen, Germany: Hogrefe.

Nunner-Winkler, G. (2007a). Moralentwicklung [Moral development]. In M. Hasselhorn \& W. Schneider (Eds.), Handbuch der Entwicklungspsychologie [Handbook of Developmental Psychology] (pp. 315-325). Göttingen, Germany: Hogrefe. 
International Journal of Child, Youth and Family Studies (2018) 9(2): 109-124

Nunner-Winkler, G. (2007b). Zum Verständnis von Moral - Entwicklungen in der Kindheit [Understanding morality - Developments in childhood]. In D. Horster (Ed.), Moralentwicklung von Kindern und Jugendlichen [Moral development of children and adolescents] (pp. 5176). Wiesbaden, Germany: VS Verlag für Sozialwissenschaften.

Nunner-Winkler, G. (2008a). Die Entwicklung des moralischen und rechtlichen Bewusstseins von Kindern und Jugendlichen [The development of the moral and legal awareness of children and adolescents]. Forensische Psychiatrie, Psychologie, Kriminologie, 2, 146-154. doi:10.1007/s11757-008-0080-X

Nunner-Winkler, G. (2008b). Zur Entwicklung moralischer Motivation [To develop moral motivation]. In W. Schneider (Ed.), Entwicklung von der Kindheit bis zum Erwachsenenalter. Befunde der Münchner Längsschnittstudie LOGIK [Development from childhood to adulthood. Findings from the Munich longitudinal study LOGIK] (pp. 103-123). Weinheim, Germany, and Basel, Switzerland: Beltz Verlag.

Oser, F., \& Althof, W. (1992). Moralische Selbstbestimmung. Modelle der Entwicklung und Erziehung im Wertebereich. Ein Lehrbuch [Moral self-determination. Models of development and education in value range. A textbook]. Stuttgart, Germany: Klett-Cotta.

Rossa, E. (2014). Kinderrechte. Das Übereinkommen über die Rechte des Kindes im internationalen und nationalen Kontext [Children's rights. The Convention on the Rights of the Child in International and National Context]. Frankfurt, Germany: PL Academic Research.

Schmidt, C. (2013). Auswertungstechniken für Leitfadeninterviews [Evaluation techniques for guide interviews]. In B. Friebertshäuser, A. Langer, \& A. Prengel (Eds.), Handbuch Qualitative Forschungsmethoden in der Erziehungswissenschaft [Handbook Qualitative Research Methods in Educational Science] (4th ed., pp. 473-486). Weinheim, Germany, and Basel, Switzerland: Beltz Juventa.

Smetana, J. G., Killen, M., \& Turiel, E. (1991). Children's reasoning about interpersonal and moral conflicts. Child Development, 62, 629-644. doi:10.2307/1131136

Steffek, C. (1999). Dilemmageschichten als methodisches und problembezogenes Verfahren zur Förderung der politischen Bildung bei Grundschülern [Dilemma stories as a methodical and problem-related method for the promotion of political education among elementary school children] (Unpublished doctoral dissertation). University of Augsburg, Augsburg, Germany. 
International Journal of Child, Youth and Family Studies (2018) 9(2): 109-124

Stellmacher, J., Sommer, G., \& Imbeck, J. (2003). Psychologische Ansätze zu einer positiven Menschenrechtserziehung - Determinanten der Einsatzbereitschaft für die Einhaltung von Menschenrechten [Psychological Approaches to Positive Human Rights Education - Determinants of Commitment to Human Rights Compliance]. In E. H. Witte (Ed.), Sozialpsychologie politischer Prozesse [Social psychology of political processes] (pp. 143-166). Lengerich, Germany: Pabst.

Swissethics. (2013). Checklist: Research on and with children and adolescents under the age of 18. Bern, Switzerland: Swiss Ethics Committees on research involving humans. Retrieved from http://www.swissethics.ch/templates_e.html

Tapp, J. L., \& Kohlberg, L. (1971). Developing senses of law and legal justice. Journal of Social Issues, 27(2), 65-91. doi:10.1111/j.1540-4560.1971.tb00654.x

Vogl, S. (2012). Alter und Methode. Ein Vergleich telefonischer und persönlicher Leitfadeninterviews mit Kindern [Age and method. A comparison of telephone and personal guide interviews with children.]. Wiesbaden, Germany: VS Verlag für Sozialwissenschaften.

Wagner, U. (2014). Qualitative Befragung mit Kindern [Qualitative interviews with children]. In A. Tillmann, S. Fleischer, \& K.-U. Hugger (Eds.), Handbuch Kinder und Medien [Handbook Children and Media] (pp. 199-210). Wiesbaden, Germany: Springer VS.

Weber, B. (2013). Philosophieren mit Kindern zum Thema Menschenrechte. Vernunft und Mitgefühl als Grundvoraussetzungen einer demokratischen Dialogkultur [Philosophizing with children about human rights. Reason and compassion as basic prerequisites of a democratic culture of dialogue]. Freiburg and Munich, Germany: Verlag Karl Alber.

Weyers, S. (2004). Moral und Delinquenz. Moralische Entwicklung und Sozialisation straffälliger Jugendlicher [Moral and delinquency. Moral development and socialization of delinquent youth]. Weinheim and Munich, Germany: Juventa Verlag.

Weyers, S. (2005). Die Entwicklung von Rechtsvorstellungen im Kontext religiös-kultureller Differenz [The development of legal concepts in the context of religious-cultural difference]. Dipf informiert. Journal des Deutschen Instituts für Internationale Pädagogische Forschung, 8, 12-17. Retrieved from https://www.dipf.de/de/forschung/publikationen/pdfpublikationen/dipf-informiert/dipf-informiert-nr.-8

Weyers, S. (2012). Wie verstehen Kinder und Jugendliche das Recht? Sechs Phasen der Entwicklung rechtlichen Denkens [How do children and adolescents understand the law? Six stages of legal thinking development]. Journal für Psychologie, 20(2), 1-31. Retrieved from https://www.journal-fuer-psychologie.de/index.php/jfp/article/download/223/264 
International Journal of Child, Youth and Family Studies (2018) 9(2): 109-124

Weyers, S. (2014). Wie verstehen Kinder und Jugendliche das Recht? Sechs Phasen der Entwicklung rechtlichen Denkens [How do children and adolescents understand the law? Six stages of legal thinking development]. In C. Kölbl \& G. Mey (Eds.), Gesellschaftsverständnis: Entwicklungspsychologische Perspektiven [Social understanding: Developmental perspectives] (pp. 105-131). Giessen and Lahn, Germany: Psychosozial Verlag.

Weyers, S., \& Köbel, N. (2010). Folterverbot oder "Rettungsfolter"? Urteile Jugendlicher über Moral, Menschenrechte und Rechtsstaatlichkeit angesichts eines realen moralischen Dilemmas [Torture ban or "rescue torture"? Judgments by young people on morality, human rights and the rule of law in the face of a real moral dilemma]. Zeitschrift für Pädagogik, 56, 604-626. Retrieved from http://www.pe-

docs.de/volltexte/2013/7162/pdf/ZfPaed_4_2010_Weyers_Koebel_Folterverbot_oder_Rettungsfolter.pdf

Weyers, S., Sujbert, M., \& Eckensberger, L. H. (2007). Recht und Unrecht aus kindlicher Sicht. Die Entwicklung rechtsanaloger Strukturen im kindlichen Denken und Handeln [Right and wrong from a child's point of view. The development of right-angled structures in the child's thinking and acting]. Münster, Germany: Waxmann. 